\title{
Determining Growing Season of Potatoes Based on Rainfall Prediction Result Using System Dynamics
}

\author{
Ida Wahyuni ${ }^{1}$, Philip Faster Eka Adipraja ${ }^{2}$, Wayan Firdaus Mahmudy ${ }^{3}$ \\ ${ }^{1,3}$ Faculty of Computer Science, Brawijaya University, 8 Veteran Road, (0341) 577911, Malang, Indonesia \\ ${ }^{1,2}$ Faculty of Informatics Engineering, STMIK Asia, Soekarno Hatta-Rembuksari 1A, (0341) 478877, Malang, Indonesia
}

\begin{abstract}
Potato has been and is a basic food for many countries. However, because of the uncertainty in rainfall patterns that have occurred since the existence of climate change make a significant impact on the outcome of potatoes production from year to year. Therefore, it needs the determination of new growing season period according to climate change. The determination of growing season is based on the result of rainfall prediction data using system dynamics ever done in previous studies to predictions of rainfall during the next five years starting in 2017-2021. Based on the modeling that has been done shows that early dry season ranges in mid-April to mid-May by the length of days in the growing season ranges from 162-192 days. The growing season prediction model has small error only about two dasarian. By the middle of the dry season, rainfall is expected to be very low which will make the potatoes into water deficit and will affect the harvest of potatoes plants which can be overcome with the irrigation system.
\end{abstract}

Copyright $@ 2018$ Institute of Advanced Engineering and Science. All rights reserved.

\section{Corresponding Author:}

Ida Wahyuni,

Faculty of Computer Science, Brawijaya University, 8 Veteran Road

(0341) 577911, Malang, Indonesia

Email: ida.wahyuni8@gmail.com

\section{INTRODUCTION}

Potato is one type of tubers plant that has a relatively high carbohydrate content [1]. Potatoes are known as a food ingredient that can replace the main crops and enter into five major world food crops other than wheat, corn, rice, and wheat flour [2]. Potatoes has been and is a basis for human food in many countries, which has a very large prospect to ensure food security in the future.

Tengger Indonesia is one of area that producing potatoes. Potatoes are the main agricultural commodities of Tengger people since a hundred years ago [3]. In the process of planting, the potatoes are very dependent on rainfall. However, due to the uncertainty in rainfall patterns that have occurred since the existence of climate change, significant impact on the result of potatoes products from year to year [4]. According to Indriantoro [1] before the existence of climate change in 2004 the production of potatoes still amounted to $14,165 \mathrm{~kg} / \mathrm{ha}$, the harvest are higher when compared to the harvest after the climate change in the year 2010 amounted to $10580 \mathrm{~kg} / \mathrm{ha}$.

Rainfall data is one of the meteorological parameters that have a greater bearing on the livelihood [5], such as for agriculture [6]. Now, agriculture industry are applies many technology for improve the harvest such as technology of digital information, sensors, monitors, and other devices [7]. So, to improve crops harvest especially potatoes, required planting time schedule in accordance with the current rainfall patterns, because rainfall variable became one of the most dominant variables, especially for rain fed agriculture commodities [8].

Integration about the timing of planting agricultural commodities with climate forecasting results was made by Hansen [9]. In that study, Hansen did integrating crop simulation models with dynamic seasonal climate forecast models is expanding in response to a perceived opportunity to add value to seasonal 
climate forecasts for agriculture. The simulation results are made is expected to be a decision support system that can assist farmers in determining the timing of planting and risk management in agriculture. In addition, similar research ever conducted by Manjula \& Rengalakshmi [10] to ensure the sustainability of agriculture and food security rain-dependent farmers in India based on the information resulting from climate prediction. In this study produced a series of step to reduction risk adaptively for rain-dependent farmers in India based on data forecasts of seasonal climate and estimates of weather for a short distance and intermediate.

Rainfall prediction was successfully done by Wahyuni et al. using system dynamics [11]. That research done make a modeling of rainfall prediction in four area in Tengger, namely Puspo Districts, Sumber District, Tosari District, and Tutur District. The value of root mean square error (RMSE) obtained in the respective districts have been quite small. The highest RMSE value is only 7.0756 that they got on one area, which is Sumber District. The method successfully predicted rainfall is well able to determine the seasonal time scales that contribute to the management and the resilience of farming systems [12]. So the results of rainfall prediction can be used as a reference for determining the growing season of potatoes crop in the future in accordance with the needs of the potatoes to rainfall.

Based on the statement described, this study will determine the growing season of potatoes crop in Tengger, Indonesia based on rainfall prediction that conducted by Wahyuni et al. [11]. To determine the growing season of potatoes is using system dynamics method for making a decision support system. Prototype created to be used as a reference in determining the growing season of potatoes in the next five years start in 2017 until 2021.

\section{LITERATURE REVIEW}

\subsection{Potato (Solanum Tuberosum) Characteristic}

Potatoes have a scientific name of Solanum tuberosum that can be planted in an area with a height of more than $500 \mathrm{~m}$ above sea level. However, where the most potential is a plateau area with an altitude between $1000-2000 \mathrm{~m}$ above sea level with temperatures around $20^{\circ} \mathrm{C}$. Therefore, Indonesia has many regions that could be planted with potatoes such as Cipanas, Lembang, Canning, Batu Malang, Tengger [3], Wonosobo, Tawangmangu, Bukit Tinggi, Kerinci, and Malino [13]. The conditions required for potato plants include the condition of the fertile soil, a little bit sandy, a lot of topsoils (fertile), ground water does not stagnate, and has a $\mathrm{pH}$ between 5 to 5.5. According to Alberta Agriculture and Forestry, in general, potato planting time approximately lasts for 80-150 days [14], the details of potato plants development stage are shown in Table 1. Potato plants need different water requirements in each grow stage. During the dry season, water deficit from rainfall occurred then generally circumvented by the irrigation system. The amount of water required for the cultivation of potatoes shown by Figure 1.

Table 1. Potato Characteristic and Requirement

\begin{tabular}{lcc}
\hline $\begin{array}{c}\text { Growth STAGE } \\
\text { 80-150 DAP }\end{array}$ & $\begin{array}{c}\text { Days After Planting } \\
\text { (DAP) }\end{array}$ & $\begin{array}{c}\text { Best } \\
\text { Temperature }\end{array}$ \\
\hline Sprout development stage & $21-30$ & $26-28{ }^{\circ} \mathrm{C}$ \\
Vegetative stage & $30-50$ & $26-28^{\circ} \mathrm{C}$ \\
Tuber initiation stage & $40-55$ & $15-18{ }^{\circ} \mathrm{C}$ \\
Tuber bulking stage & $50-80$ & $15-18{ }^{\circ} \mathrm{C}$ \\
Tuber maturation stage & $80-95$ & $15-18{ }^{\circ} \mathrm{C}$ \\
Harvest & \pm 100 & $15-18{ }^{\circ} \mathrm{C}$ \\
\hline
\end{tabular}

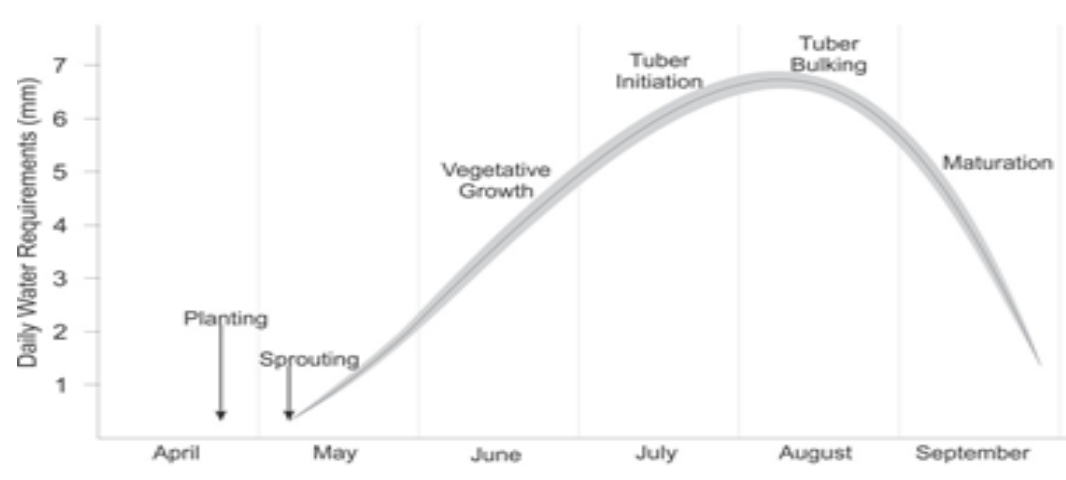

Figure 1. Potato grow stage and water requirement [14] 


\subsection{System Dynamics}

A system dynamics is a modeling and simulation approach for analysis and designing a new policy with the help of computers. System dynamic can be distinguished by the presence of dependency among variables, mutualism interaction, information feedback, and the causal loop [15]. Systems dynamics are often used to manage, model, and simulate new policies based on existing systems.

The system dynamics approach begins with identifying the main problems, especially when it could be defined as a time series graph. Then models is developed by identify the variables that affect the main problem including circular causality and loops of information feedback. The developed models is used to identifying stock, accumulations, and flows in the system thus developing a Stock and Flow Diagram (SFD). The SFD is used as a simulation model which runs with the aid of a computer. Hereafter, the policymaker need to understand the simulation result and use it as a decision support materials on implementing changes in making policy changes for a better system [15].

\subsection{Rainfall Prediction Using System Dynamic}

Rainfall is an important things in agriculture so early prediction of rainfall is good for the better economic growth of agriculture country [6]. A system dynamics is a modeling and simulation approach for analysis and designing a new policy with the help of computers. System dynamic can be distinguished by the presence of dependency among variables, mutualism interaction, information feedback, and the causal loop [15].

System dynamics has been used by Wahyuni et al. to model and simulate rainfall prediction [11]. The study was conducted to predict the rainfall in the area in four districts in Tengger such as Puspo, Sumber, Tosari, and Tutur. Rainfall prediction models incorporate various influence factors such as temperature and humidity. Models that has been used by Wahyuni et al. can be seen in Figure 2 [11].

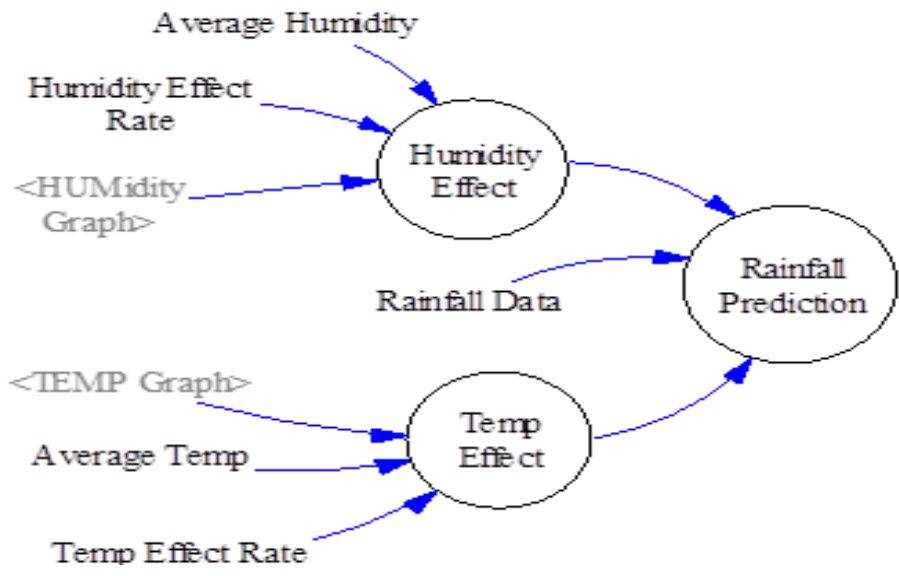

Figure 2. Stock and flow diagram model of rainfall prediction

The smallest RMSE obtained at the Tosari which is 6.4219 and the largest RMSE obtained at the Sumber which is 7.0756. Validation and value of RMSE which obtained in each district can be seen more clearly in Table 2.

Table 2. Validation and RMSE of Rainfall Prediction Using System Dynamics

\begin{tabular}{lccc}
\hline Location & E1 & E2 & RMSE \\
\hline Puspo & $2.9 \%$ & $26.3 \%$ & 6.7672 \\
Sumber & $2.77 \%$ & $29.9 \%$ & 7.0756 \\
Tosari & $1.6 \%$ & $26.7 \%$ & 6.4219 \\
Tutur & $1.0 \%$ & $28.4 \%$ & 6.581 \\
\hline
\end{tabular}

Methods of system dynamics used by Wahyuni et al. [11] successfully predict rainfall with smaller RMSE value than the other methods that have been used to predict the rainfall such as GSTAR-SUR [4], Tsukamoto FIS [16], Tsukamoto FIS with GA [17]. The predicted results using system dynamics can predict 
rainfall with a small error, hereafter it can be used to determine the potato growing season in the future in accordance with the needs of the potato to rainfall [12].

\section{MODELING}

\subsection{Season Prediction Modeling}

The beginning and the end of the dry season can be determined based on the rainfall data. The dry season begins when rainfall is below $50 \mathrm{~mm}$ or shower rain types $(44.52 \mathrm{~mm} / \mathrm{h})$ followed by next two subsequent dasarian were also below $50 \mathrm{~mm}$ or widespread rain types $(14.21 \mathrm{~mm} / \mathrm{h})$ [18]. The ends of dry season are determined when the rainfall of two previous dasarian still below $50 \mathrm{~mm}$ and the next dasarian rainfall exceeding $50 \mathrm{~mm}$ [19]. Stock and flow diagram model of dry season prediction show in Figure 3.

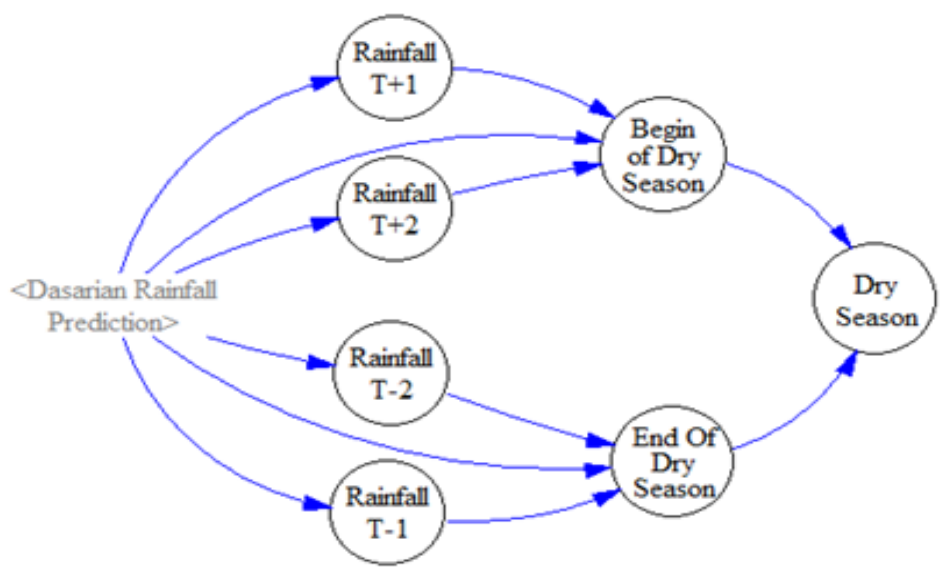

Figure 3. Stock and flow diagram model of dry season prediction

The data used is the BMKG data which formed in the dasarian units or average rainfall for ten days [20]. To determine the amount of rainfall data for ten days simply multiplied the dasarian data by ten. Detail explanation of dasarian data shown in Table 3.

Table 3. Validation and RMSE of Rainfall Prediction Using System Dynamics

\begin{tabular}{lc}
\hline \multicolumn{1}{c}{ Category } & Calendar Date \\
\hline Dasarian I & $1^{\text {st }}-10^{\text {th }}$ \\
Dasarian II & $11^{\text {th }}-20^{\text {th }}$ \\
Dasarian III & $21^{\text {st }}-$ end of the month \\
\hline
\end{tabular}

\subsection{Growing Season Modeling}

The best time to plant potatoes is at the end of the rainy season and it can well growth with air temperatures around $20^{\circ} \mathrm{C}$. However, the potato can also be planted at the beginning of the rainy season on the condition that the potatoes must be aged two months or have large tuber when heavy rain occurred [10]. In other words, determining the beginning and the end of the dry season will affect the potato growing season prediction with considering the air temperature. The dependence among variables which affect the determining of potato growing season can be depicted in Figure 4.

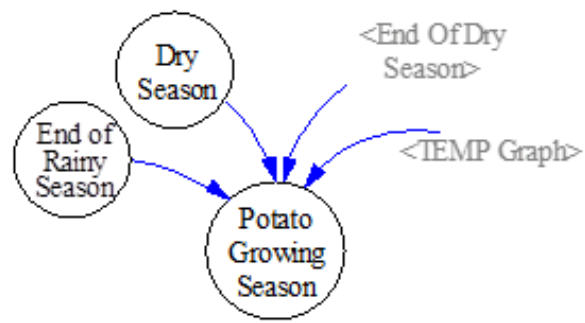

Figure 4. Stock and flow diagram of potato growing season 


\section{RESULT AND DISCUSSION}

\subsection{Season Prediction}

Results of rainfall prediction can be used to predict the beginning and end of the dry season which can be used to determine the suitable time for potato planting. The simulation results are used to calculate the beginning and the end of dry season in the past 10 years from 2005 to 2014 . Determination of dry season is shown in dasarian units and the error rate of beginning and ending of dry season can be seen in Table 4. By using the system dynamics approach, the growing season can be simulated with the average error in beginning and ending of the dry season only about two dasarian which can be see in Table 4 .

Table 4.Validation and RMSE of Rainfall Prediction Using System Dynamics

\begin{tabular}{ccccc}
\hline \multirow{2}{*}{ Year } & \multirow{2}{*}{ Actual } & Predicted & The Beginning of Dry Season & The End of Dry Season \\
\cline { 3 - 5 } 2005 & Apr 3-Nov 3 & May 1-Oct 3 & -1 & 3 \\
2006 & Jun 1-Dec 1 & Jun 1-Oct 3 & 0 & 7 \\
2007 & Apr 3-Oct 3 & May 2-Oct 3 & -1 & 0 \\
2008 & Apr 2-Oct 1 & Jun 3-Oct 3 & -7 & -2 \\
2009 & Jun 1-Nov 1 & May 3-Oct 3 & 1 & 1 \\
2010 & Jun 3-Aug 3 & May 2-Oct 3 & 4 & -6 \\
2011 & May 3-Oct 2 & Jun 1-Oct 3 & -1 & -1 \\
2012 & May 2-Nov 1 & May 3-Oct 2 & -1 & 2 \\
2013 & Jul 3-Nov 1 & May 3-Oct 2 & 6 & 2 \\
2014 & May 1-Nov 1 & May 3-Oct 2 & -2 & 2 \\
\hline \multicolumn{7}{c}{ Average Error (Unit in Dasarian) } & 2 & 2
\end{tabular}

Data from rainfall prediction using system dynamics that conducted in previous studies are shown in the dasarian units [11]. Rainfall prediction results in year 2005 until 2014 is clearly illustrated in Figure 5 until Figure 7.

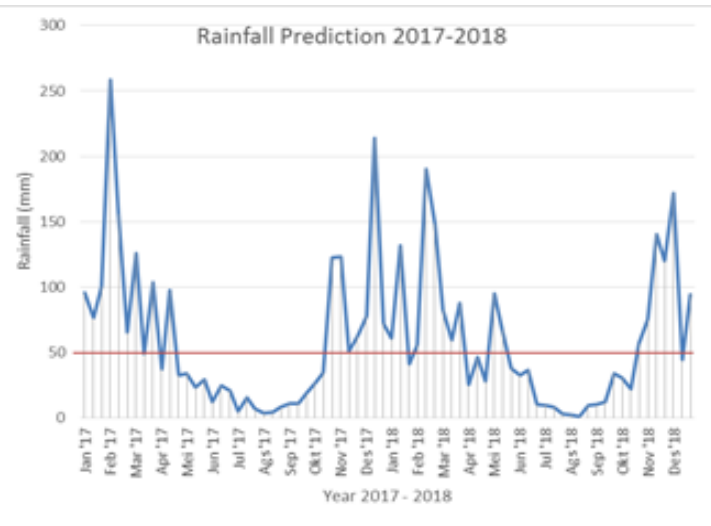

Figure 5. Rainfall prediction result in 2017-2018

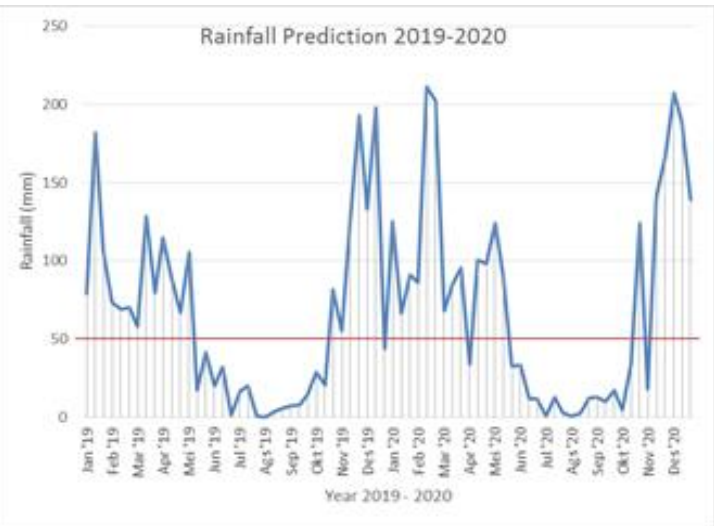

Figure 6. Rainfall prediction result in 2019-2020

In Figure 5 until Figure 7 shown the limits of rainfall that distinguishes the rainy season and dry season. It can be seen that the start of the dry season begins around April to June. From the data obtaine, the prediction results of dry and rainy season shown in Table 5.

Table 5. Prediction Results of Dry and Rainy Season in Tengger, Indonesia

\begin{tabular}{ccc}
\hline Year & Dry Season & Rainy Season \\
\hline $2017-2018$ & Apr Dasarian III-Oct Dasarian II & Oct Dasarian III-May Dasarian II \\
$2018-2019$ & May Dasarian III-Oct Dasarian II & Oct Dasarian III-May Dasarian I \\
$2019-2020$ & May Dasarian II-Oct Dasarian II & Oct Dasarian III-June Dasarian II \\
$2020-2021$ & May Dasarian III-Oct Dasarian II & Oct Dasarian III-Apr Dasarian II \\
2021 & Apr Dasarian III-Oct Dasarian II & - \\
\hline
\end{tabular}


Temperature data obtained from the Meteorological, Climatological and Geophysical Agency of Indonesia in the last 14 years from 2000 until 2014 did not show any significant change [20]. Graph of average temperature over a period of 1 year is shown in Figure 8.

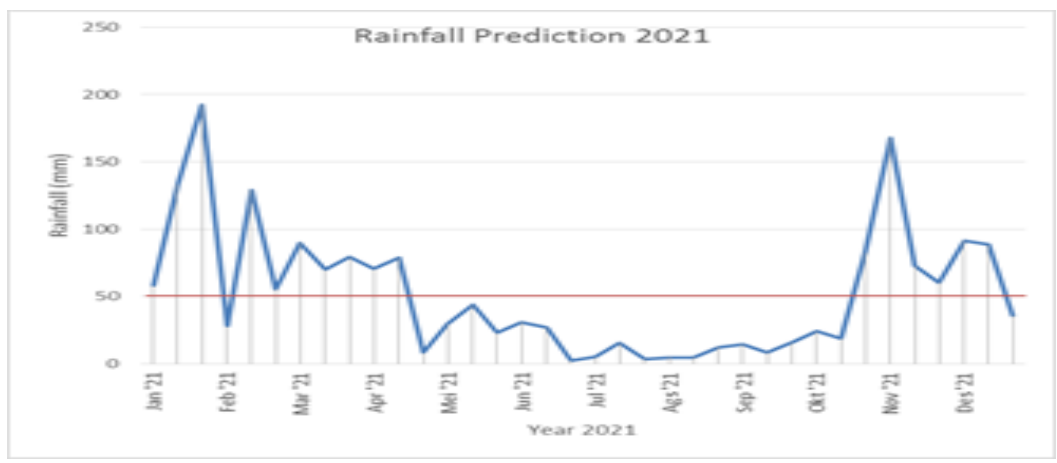

Figure 7. Rainfall prediction result in 2021

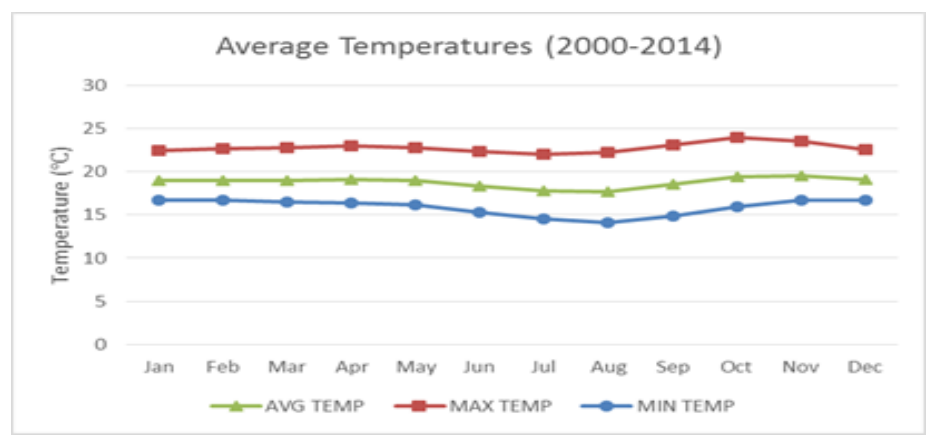

Figure 8. Average temperature data from 2000-2014

\section{GROWING SEASON PREDICTION}

Prediction of potato growing season can be done based on the season prediction which was generated for the next five years from 2017 to 2021. The temperature the end of the rainy season or at the beginning of the dry season shows an average temperature below $20^{\circ} \mathrm{C}$, indicating that it is a suitable time to start planting potatoes. Growing season prediction of potatoes and the length of the season are shown in Table 6.

Table 6. Prediction Results of Potato Planting Time in the Dry Season

\begin{tabular}{ccc}
\hline Year & Dry Season & Num. of Days \\
\hline 2017 & Apr Dasarian II-Oct Dasarian II & 192 \\
2018 & May Dasarian II-Oct Dasarian II & 162 \\
2019 & May Dasarian I-Oct Dasarian II & 172 \\
2020 & May Dasarian II-Oct Dasarian II & 162 \\
2021 & Apr Dasarian II-Oct Dasarian II & 192 \\
\hline
\end{tabular}

Growing season prediction of potatoes that shown in Table 6 is used to decision support system for farmer to begin grows potatoes. Result of growing season prediction has a small error as shown in Table 4 . So, this growing season prediction could improve the production of potato harvest in the future.

\section{CONCLUSION}

System dynamics modeling can be used as a prediction tool for decision support in determining potato growing season. The prediction is based on rainfall prediction data for the next five years starting from 2017-2021 using system dynamics approach in previous studies [11]. The simulation results using system

Determining Growing Season of Potatoes Based on Rainfall Prediction Result Using... (Ida Wahyuni) 
dynamics shows that early planting time of potatoes is around mid-April to mid-May with the number of days in a season between 162-192 days. Growing season prediction in beginning and ending of dry season only has average error about 2 dasarian. This result is good because the error is less than 4 dasarian or 1 month. So, this result can be use by the potatoes farmer to start planting potatoes.

In the mid-grow stage of potato require water about $7 \mathrm{~mm}$ per day [14]. Based on the graph of rainfall prediction, the amount of rainfall in the mid drought is very low which may make potato being a deficit of water that can be overcome by the irrigation system. The next research will be conducted simulation potato planting season based on the data of rainfall prediction using a combination of methods ANFIS-GA [21] and system dynamics.

\section{REFERENCES}

[1] S. Indriantoro, "Dampak Perubahan Iklim Terhadap Usaha Tani Kentang Dataran Tinggi Tengger Studi Kasus di Desa Ngadisari Kecamatan Sukapura Kabupaten Probolinggo (Climate Change Impacts on Tengger Tengger High Potato Farmers Case Study in Ngadisari Village, Sukapura Distr," Agribisnis, pp. 1-8, 2010.

[2] G. Wattimena, "Prospek Plasma Nutfah Kentang Dalam Mendukung Swasembada Benih Kentang di Indonesia (Potato Germplasm Prospects to Support The Self-Sufficiency of Potato Seed in Indonesia)," Pus. Penelit. Sumberd. Hayati dan Bioteknol. IPB dan Jur. Agrohort, Fak. Pertan. IPB, no. April, 2006.

[3] J. Batoro, D. Setiadi, dan T. Chikmawati, "Pengetahuan Tentang Tumbuhan Masyarakat Tengger di Bromo Tengger Semeru Jawa Timur (Knowledge of Community About Plant in Tengger Bromo Tengger Semeru in East Java)," $J$. Wacana-J. Sos. dan Hum., pp. 1-10, 2006.

[4] A. Iriany, W. F. Mahmudy, A. D. Sulistyono, dan S. C. Nisak, "GSTAR-SUR Model for Rainfall Forecasting in Tengger Region, East Java,” 1st Int. Conf. Pure Appl. Res. Univ. Muhammadiyah Malang, 21-22 August, no. 1, pp. $1-8,2015$.

[5] M. M. Nia, J. Din, H. Y. Lam, dan A. D. Panagopoulos, "Stochastic approach to a rain attenuation time seris synthesizer for heavy rain regions," International Journal of Electrical and Computer Engineering (IJECE), vol. 6, no. 5, pp. 2379-2386, 2016.

[6] Y. J. N. Kumar dan T. V. R. Kanth, "GIS-MAP based Spatial Analysis of Rainfall Data of Andhra Pradesh and Telangana States using R,” International Journal of Electrical and Computer Engineering (IJECE). vol. 7, no. 1, pp. 460-468, 2017.

[7] E. Yulian, T. Adesta, dan D. Agusman, "Internet of Things ( IoT ) in Agriculture Industries," International Journal of Electrical and Computer Engineering (IJECE), vol. 5, no. 4, pp. 376-382, 2017.

[8] S. Dercon, "Growth and shocks: Evidence from rural Ethiopia," J. Dev. Econ., vol. 74, no. 2, pp. 309-329, 2004.

[9] J. W. Hansen, "Integrating seasonal climate prediction and agricultural models for insights into agricultural practice,” Philos. Trans. R. Soc. Lond. B. Biol. Sci., vol. 360, no. 1463, pp. 2037-2047, 2005.

[10] M. Manjula dan R. Rengalakshmi, "Seasonal Climate Information for Ensuring Agricultural Sustainability and Food Security of Small Holder Rainfed Farmers: Experience from India," J. Chem. Inf. Model., vol. 53, pp. 1689-1699, 2013.

[11] I. Wahyuni, P. F. E. Adipraja, W. F. Mahmudy, dan A. Iriany, "Rainfall Prediction in Tengger Indonesia: A System Dynamics Approach,” Int. Conf. Informatics, Robot. Network, Control Syst. 2016, pp. 1-8, 2016.

[12] J. W. Hansen dan M. V. K. Sivakumar, "Advances in applying climate prediction to agriculture," Clim. Res., vol. 33, no. 1, pp. 1-2, 2006.

[13] H. Sunarjono, Bertanam 36 Jenis Sayur (Planting 36 Types of Vegetable). Jakarta: Penebar Swadaya Grup, 2013.

[14] Alberta Agriculture and Forestry, Irrigation Scheduling for Potato in Southern Alberta, no. March. Alberta: Alberta Agriculture and Forestry, 2011

[15] G. P. Richardson, Encyclopedia of Operations Research and Management Science: System Dynamics. 2013.

[16] I. Wahyuni, W. F. Mahmudy, dan A. Iryani, "Rainfall Prediction in Tengger Region Indonesia Using Tsukamoto Fuzzy Inference System,” 1st Int. Conf. Inf. Technol. Inf. Syst. Electr. Eng. ICITISEE 2016, vol. 16, pp. 130-135, 2016.

[17] I. Wahyuni dan W. F. Mahmudy, "Rainfall Prediction in Tengger-Indonesia Using Hybrid Tsukamoto FIS and Genetic Algorithm,” J. ICT Res. Appl., vol. 11, no. 1, hal. 38-54, 2017.

[18] O. Adetan dan O. O. Obiyemi, "A analysis of raindrop diameters for rainfall attenuation in Southern Africa," International Journal of Electrical and Computer Engineering (IJECE), vol. 6, no. 1, pp. 82-89, 2016.

[19] A. Ulfah dan W. Sulistya, "Penentuan Kriteria Musim Alternatif Di Wilayah Jawa Timur (Determination of Alternative Season In East Java),” J. Meteorol. Geophys., no. 5, pp. 145-153, 2014.

[20] BMKG, "Online Database Data Center-BMKG," Meteorological, Climatological, and Geophysical Agency, 2016. [Daring]. Tersedia pada: http://dataonline.bmkg.go.id.

[21] I. Wahyuni, W. F. Mahmudy, dan A. Iriany, "Rainfall Prediction using Hybrid Adaptive Neuro Fuzzy Inference System (ANFIS) and Genetic Algorithm," J. Telecommun. Electron. Comput. Eng., vol. 9, no. 2-8, pp. 51-56, 2017 